Agrovoc descriptors: beauveria bassiana, herbicides, pesticides, entomogenous fungi, inhibition, mycelium, growth, fungal morphology

Agris category code: $\mathrm{H} 20$

\title{
Compatibility of selected herbicides with entomopathogenic fungus Beauveria bassiana (Bals.) Vuill
}

\author{
Franci Aco CELAR ${ }^{1}$, Katarina $\mathrm{KOS}^{2}$
}

Received December 22, 2011; accepted January 19, 2012.

Delo je prispelo 22. decembera 2011, sprejeto 19. januarja 2012.

\begin{abstract}
The in vitro effect of five commonly used herbicides viz., pyridate, fluazifop-P-butyl, foramsulfuron, tembotrione and Smetolachlor on mycelial growth of entomopathogenic fungus Beauveria bassiana (ATCC 74040) was evaluated each at different concentrations: $100,75,50,25,12.5,6.25$ and $0 \%$ of recommended field application rate on PDA agar plates at 15 and $25^{\circ} \mathrm{C}$. The herbicides tested were classified in $1-4$ scoring categories based on reduction in mycelial growth: $1=$ harmless $(<25 \%$ reduction), $2=$ slightly harmful $(25-50 \%), 3$ $=$ moderately harmful $(51-75 \%)$, harmful $(>75 \%)$ in toxicity tests. All the five herbicides had fungistatic effect to $B$. bassiana at varying intensities depending on their concentrations in medium. The present study showed that $B$. bassiana is very sensitive to the herbicides tested, particularly at recommended as well as lower field dosage. The selected herbicides foramsulfuron, tembotrione and S-metolachlor have strong fungistatic effect on mycelial growth (> 75\% inhibition) at $15{ }^{\circ} \mathrm{C}$ and concentrations from 50 to $100 \%$. Foramsulfuron has fungicidal effect at $100 \%$ concentration. Foramsulfuron, tembotrione and S-metolachlor were less inhibitory at 25 than at $15{ }^{\circ} \mathrm{C}$, but the temperature had no influence on reduction of mycelial growth at pyridate and fluazifop-P-butyl. Of the herbicides tested, pyridate and fluazifop-P-butyl showed less adverse effects and are probably compatible with $B$. bassiana in the field. However, extensive field studies complemented by parallel laboratory experiments should consider assessing the interaction between selected herbicides and $B$. bassiana isolates to evaluate their ecological impact in cropped environments.
\end{abstract}

Key words: Beauveria bassiana, herbicides, inhibition, mycelial growth, compatibility
IZVLEČEK

\author{
KOMPATIBILNOST IZBRANIH HERBICIDOV $Z$ \\ ENTOMOPATOGENO GLIVO Beauveria bassiana (Bals.) \\ Vuill
}

$\mathrm{V}$ in vitro poskusih smo na PDA agarnih ploščah in temperaturah 15 ter $25{ }^{\circ} \mathrm{C}$ preučevali učinek petih pogosto uporabljanih herbicidov, in sicer piridata, fluazifop-P-butila, foramsulfurona, tembotriona in S-metolaklora na rast micelija entomopatogene glive $B$. bassiana (ATCC 74040) pri različnih koncentracijah: $100,75,50,25,12,5,6,25$ in $0 \%$ priporočenega poljskega odmerka. Glede na inhibicijo rasti micelija smo po toksikoloških testih preučevane herbicide razvrstili v štiri razrede: $1=$ neškodljiv ( $<25 \%$ inhibicija $), 2=$ malo škodljiv $(25-50 \%), 3=$ zmerno škodljiv $(51-75 \%), 4$ $=$ škodljiv $(>75 \%)$. Vseh pet herbicidov ima fungistatičen učinek na glivo $B$. bassiana, na obseg pa vpliva njihova koncentracija v gojišču. Raziskava je pokazala, da je gliva $B$. bassiana zelo občutljiva na preizkušane herbicide, posebej pri priporočenih poljskih koncentracijah, pa tudi pri manjših odmerkih. Pri temperaturi $15{ }^{\circ} \mathrm{C}$ in koncentracijah od 50 do $100 \%$ imajo herbicidi na podlagi foramsulfurona, tembotriona in S-metolaklora izrazit fungistatičen učinek $(>75 \%$ inhibicija), pri $100 \%$ odmerku pa ima foramsulfuron celo fungicidni učinek. Foramsulfuron, tembotrion in S-metolaklor so bili manj inhibitorni pri 25 kot $15{ }^{\circ} \mathrm{C}$. Temperatura ni vplivala na inhibicijo rasti micelija pri piridatu in fluazifop-Pbutilu. Od vseh preizkušanih herbicidov sta imela piridat in fluazifop-P-butil najmanj zaviralnih učinkov in bi jih lahko uporabljali na pridelovalnih površinah skupaj $\mathrm{z}$ glivo $B$. bassiana. Poleg laboratorijskih testov $\mathrm{s}$ herbicidi bi morali izvajati vzporedne poskuse na pridelovalnih površinah, da bi dejansko izvrednotili njihov ekološki vpliv na glivo $B$. bassiana

Ključne besede: Beauveria bassiana, herbicidi, inhibicija, rast micelija, kompatibilnost

\footnotetext{
1 izr. prof. dr., Katedra za fitomedicino, kmetijsko tehniko, poljedelstvo, pašništvo in travništvo, Jamnikarjeva 101, SI-1111 Ljubljana, e-pošta: franci.celar@bf.uni-lj.si

2 asist., univ. dipl. inž. agr., prav tam
} 


\section{INTRODUCTION}

Entomopathogenic fungi have an important role in biological control of various harmful insects and mites (Keller, 1991). Beauveria bassiana (Bals.) Vuill. is the most studied and well known entomopathogenic fungus and is frequently used in commercially available mycoinsecticides (Inglis et al., 2001).

Numerous organisms, physical and chemical factors of soil ecosystem and agrochemicals that are commonly used in crop production, influence entomopathogenic fungi present in soil. Their diversity and number is also affected by plant species present in crop rotation, cultural practices, intensity of soil use and fertilization with mineral and organic fertilizers (Hummel et al., 2002; Klingen and Haukeland, 2006).

Pesticides are anthropogenic factor with synergistic or antagonistic influence on pests as well as their pathogens (entomopathogenic fungi) and through that on their efficiency (Benz, 1987). Optimally chosen pesticides can minimize their harmful effect on entomopathogenic fungi (Luz et al., 2007; Sterk et al., 1999). The efficacy of entomopathogenic fungus $B$. bassiana incorporated in the soil is affected by regular pesticide usage in agronomical practice, because it often leads to their accumulation in soil. It is important to know the compatibility of pesticides (including herbicides) with entomopathogenic fungi to be able to include mycoinsecticides with $B$. bassiana in integrated crop protection (Ambethgar et al., 2009).

Non-target effects of pesticides on beneficial organisms are gaining their importance in developing active substances for new insecticides and in re-registration of existing ones in European community. Side effects of pesticides (especially of fungicides) on entomopathogenic fungi and the influence of entomopathogenic fungi on other useful microorganisms are tested from microbiological point of view (Sterk et al., 2003).

Due to the complexity of natural environment, expenses and duration of field experiments it is important to make some preliminary test in vitro where it is possible to control all the factors. Despite all that, the obtained results can not be directly used in agronomical practice. In vivo field test must follow in order to finally confirm or reject the outcome of laboratory tests (Mietkiewski et al., 1997; Moorhouse et al., 1992).

Data obtained by in vitro and some in vivo experiments suggest a general sensitivity of entomopathogenic fungi to some herbicides (Ambethgar et al., 2009; Gardner and Storey, 1985; Harrison and Gardner, 1992; Keller, 1986; Mietkiewski et al., 1989; Poprawski and Majchrowicz, 1995; Todorova et al., 1998; Wardle and Parkinson, 1992).

We have observed a strong inhibitory effect of some tested herbicides on mycelium growth of $B$. bassiana in our previous laboratory experiments. Herbicides even had a stronger detrimental effect in comparison to fungicides (Celar et al., 2011). Based on these results we have extended our survey to some other herbicides commonly used in Slovenian crop production and the results of this study are presented in this paper.

\section{MATERIALS AND METHODS}

Our test method is based on the guidelines for testing sideeffects of pesticides on $B$. bassiana (Coremans-Pelseneer, 1994), but small plugs of mycelium were placed on the treated medium with different herbicide concentrations, instead of spore suspension inoculation. Five herbicides were used in our essay (Table 1). 
Table 1: Basic data about herbicides used in laboratory essay.

Preglednica 1: Osnovni podatki o herbicidih, uporabljenih v laboratorijskem preizkušanju.

\begin{tabular}{|c|c|c|c|c|c|c|}
\hline HERBICIDE & $\begin{array}{c}\text { Active } \\
\text { ingedient }\end{array}$ & a.i. $\%$ & $\begin{array}{c}\text { Dose rate/ } \\
\text { ha }\end{array}$ & \begin{tabular}{|c|}
$\begin{array}{c}\text { Water per ha } \\
\text { (l) } \\
\text { (recommended) }\end{array}$ \\
\end{tabular} & \begin{tabular}{|c|} 
FD $^{*}$ \\
$\mathrm{ml}(\mathrm{g}) / /$
\end{tabular} & Manufacturer \\
\hline Lentagran WP & pyridate & 45 & $2 \mathrm{~kg}$ & $200-400$ & 2 & $\begin{array}{l}\text { Belchim Crop } \\
\text { Protection }\end{array}$ \\
\hline Fusilade Forte & \begin{tabular}{|c}
$\begin{array}{c}\text { fluazifop-P- } \\
\text { butyl }\end{array}$ \\
\end{tabular} & 15 & 21 & $200-300$ & 2 & Syngenta \\
\hline Equip & foramsulfuron & 2,25 & 2,51 & $200-300$ & 2,5 & Bayer CS \\
\hline Laudis & tembotrione & 4,4 & 1,51 & $200-300$ & 1,5 & Bayer CS \\
\hline $\begin{array}{l}\text { Dual Gold } 960 \\
\text { EC }\end{array}$ & S-metolchlor & 96 & 1,51 & $200-500$ & 1,5 & Syngenta \\
\hline
\end{tabular}

$* 100 \%$ field dosage used in essay - herbicide concentration in medium

*100\% poljski odmerek v poskusu - koncentracija herbicida v gojišču

To isolate entomopathogenic fungus $B$. bassiana from a product Naturalis ${ }^{\circledR}$ (INTRACHEM Bio Italia S.p.A.) in pure culture, a standard dilution method on potato dextrose agar (PDA - Merck) medium was used. This mycoinsecticide has permission for use in Slovenia and contains B. bassiana isolate ATCC 74040.

Just before solidification of sterile PDA medium, herbicide was added in different concentrations; $100 \%$ of recommended field dosage rate, $75 \%, 50 \%, 25 \%, 12.5 \%$, and $6.25 \%$. Treated medium was than poured in sterile Petri dishes $(9 \mathrm{~cm}$ diameter), $15 \mathrm{ml}$ in each and cooled. Recommended water consumption for herbicides is between 200 and $500 \mathrm{~L} / \mathrm{ha}$, but for our essay common water consumption of $1.000 \mathrm{~L} / \mathrm{ha}$ was used to prepare agar plates. This means that initial laboratory concentrations in agar plates were 2 to 5 -times lower that it would be in actual field application suspension. E.g. dose rate of Lentagran is $2 \mathrm{~kg} / \mathrm{ha}$, our initial $(100 \%)$ concentration was $0,2 \%$. Control was sterile PDA medium without herbicides added. A small plug (Ø $5 \mathrm{~mm})$ of $B$. bassiana inocubated in the dark on PDA plates at $25^{\circ} \mathrm{C}$ for 14 days, was inverted in the center of prepared PDA plates with herbicide and control. Three repetitions were made for each treatment. Inoculated agar plates were then incubated in dark in growth chambers at 15 and $25^{\circ} \mathrm{C}$ with $60 \%$ relative air humidity.
After 7 and 14 days, mycelial growth was measured with image analyzer (Nikon NIS Elements BR 2.30).

The fungus-herbicides compatibility data were analyzed according to IOBC classification scheme (Sterk et al., 2003). The replicated fungus radial growth data were averaged and were expressed as percentage of growth inhibition in comparison to corresponding control following Hokkanen and Kotiluoto (1992).

$$
I(\%)=\frac{C-H}{C} \cdot 100
$$

Where: I, C, H stand for percentage of growth inhibition, growth of fungus in control and growth of fungus in herbicidal medium, respectively. The herbicides were further classified into the toxicity categories proposed by the IOBC working group: Class 1: harmless ( $<25 \%$ inhibition), Class 2: slightly harmful (25\%-50\%), Class 3: moderately harmful (51\%-75\%) and Class 4: harmful (>75\%). The effect of the herbicides was scored as fungicidal if growth dropped totally, as otherwise it was taken as fungistatic.

All data were analysed using Student-Newman-Keuls test, $\mathrm{P}<$ 0.05 (Statgraphics Plus Professional 5.1; StatPoint Technologies, Inc.).

\section{RESULTS AND DISCUSSION}

Average relative mycelium growth rates of $B$. bassiana on agar plates containing different herbicides in six concentrations are presented in Figure 1 and 2 . Herbicides based on foramsulfuron, tembotrione and $\mathrm{S}$ metolachlor at $15^{\circ} \mathrm{C}$ and $50-100 \%$ concentration have a strong fungistatic effect (>75\% of growth inhibition). Foramsulfuron at the highest tested concentration $(100 \%)$ even had a fungicidal effect (the mycelium did not grow). The inhibitory effect of these three herbicides on mycelium growth is decreasing with the decreasing concentration in agar plates, but there are no statistically significant differences in concentrations higher or equal to $50 \%$, where the inhibition rate reaches 90 to $100 \%$ (Figure 1, Table 2). Even 25\% concentration of herbicides results in high growth inhibitory effect (82-90\%). Similar, $12.5 \%$ concentration inhibits mycelium growth for $71-74 \%$. Even at the lowest tested concentration (6.25\%) the 
inhibitory effect of these three herbicides is so strong, that they are assigned to class $2(25-50 \%$, slightly harmful). Other two tested herbicides, i.e. pyridate and fluazifop-P-butyl, had a much lower inhibitory effect on mycelium growth in comparison to previously mentioned three herbicides. Pyridate and fluazifop-P- butyl were moderately harmful (51-75\% of inhibition, class 3) at higher concentrations $(50-100 \%)$. However, at lower tested concentrations $(6.25-25 \%)$ herbicides can by assigned to class 2 (slightly harmful) or class 1 (harmless) based on the inhibition rates, as in the case of fluazifop-P-butyl.

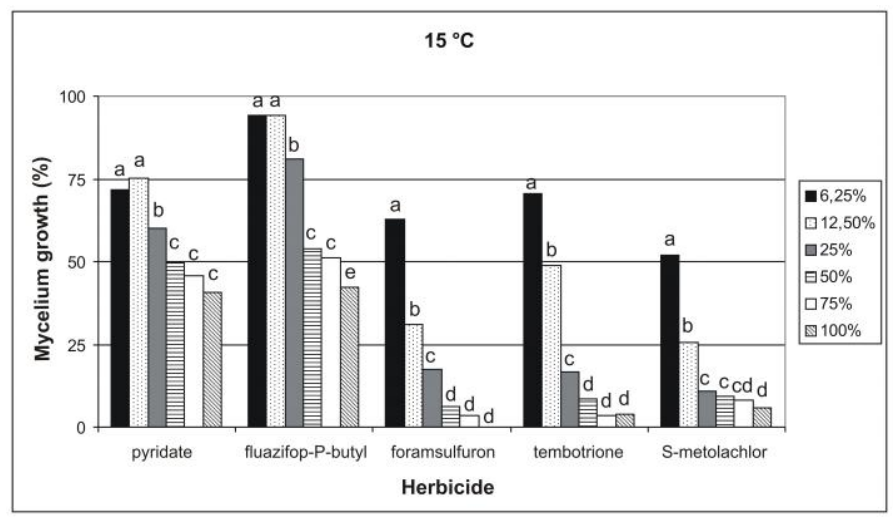

Figure 1: Mean relative mycelium growth of B. bassiana at different herbicides and concentrations according to control treatment in \% (control treatment $100 \%$ ) at $15{ }^{\circ} \mathrm{C}$ after 14 days (different lowercase letters show significant differences in mean relative mycelial growth among different concentrations within each herbicide).

Slika 1: Povprečni relativni prirasti micelija glive B. bassiana pri različnih herbicidih in koncentracijah v primerjavi s kontrolo izraženi v \% (kontrola je $100 \%$ ) pri $15^{\circ} \mathrm{C}$ po 14 dneh (različne črke pomenijo statistično značilne razlike v priraščanju micelija pri različnih koncentracijah v okviru enega herbicida).

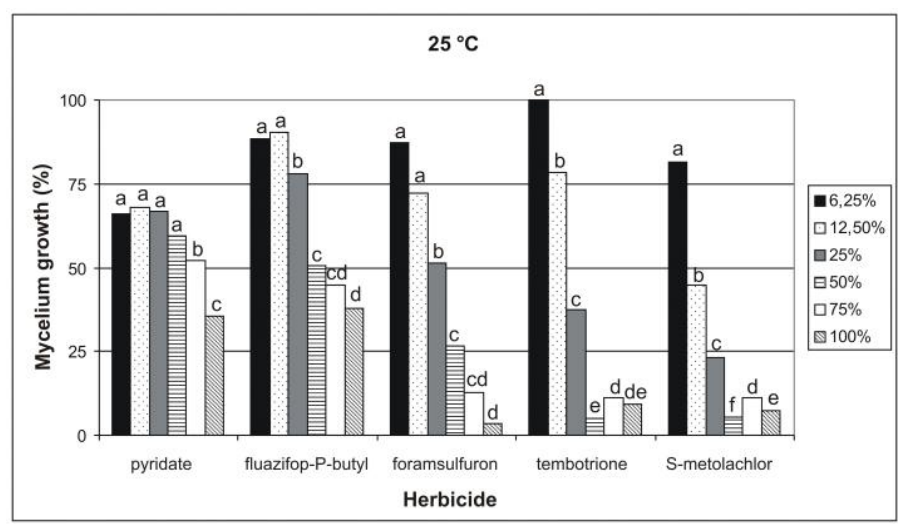

Figure 2: Mean relative mycelium growth of B. bassiana at different herbicides and concentrations according to control treatment in \% (control treatment $100 \%$ ) at $25^{\circ} \mathrm{C}$ after 14 days (different lowercase letters show significant differences in mean relative mycelial growth among different concentrations within each herbicide).

Slika 2: Povprečni relativni prirasti micelija glive B. bassiana pri različnih herbicidih in koncentracijah v primerjavi s kontrolo izraženi v \% (kontrola je $100 \%$ ) pri $25^{\circ} \mathrm{C}$ po 14 dneh (različne črke pomenijo statistično značilne razlike v priraščanju micelija pri različnih koncentracijah v okviru enega herbicida).

Similar results were obtained at $25^{\circ} \mathrm{C}$, where herbicides based on foramsulfuron, tembotrione, and S- metolachlor had a significant growth-inhibitory effect, especially at $50-100 \%$ concentrations (Figure 2, Table 
2). All three previously mentioned herbicides are classified as harmless (class 1) at lowest tested concentration based on growth inhibition rates. The mycelium growth inhibition rates at lower tested concentrations $(6.25-25 \%)$ are much lower at $25^{\circ} \mathrm{C}$ in comparison to those at $15^{\circ} \mathrm{C}$.

Lower fungistatic effect of herbicides at higher temperature could be explained with the better vitality of $B$. bassiana at higher temperatures (its optimum temperatures for development are between 20 and $26^{\circ} \mathrm{C}$ ). Average growth rates of $\mathrm{B}$. bassiana at $25^{\circ} \mathrm{C}$ are up to 5 -times higher compared to $15^{\circ} \mathrm{C}$. However, this does not explain the results for pyridate and fluazifop-Pbutyl, where the temperature had no significant effect on mycelium growth inhibition (Figure 1 and 2).
$100 \%$ concentration of tested herbicides was calculated based on the $1000 \mathrm{~L}$ of water used for treatment of one hectare. It can be seen in Table 1, that the manufacturer recommends 2- to 5-times less water use (200-500 L). This means 2- to 5- times higher herbicide concentration for the treatment. This decision for amount of water used was made in order to make concentrations of individual herbicides more comparable. B. bassiana incorporated in the soil is never exposed to the herbicide concentration used for plant treatment. Our highest concentration of herbicide on agar plates $(100 \%)$, means only $20-50 \%$ of the concentration used for plant treatment on the field (depends on the type of herbicide).

Table 2: Percent of mycelium growth inhibition of B. bassiana at different herbicides and concentrations according to control treatment at 15 and $25^{\circ} \mathrm{C}$ after 14 days and classification in scoring categories based on reduction in mycelial growth.point mutations.

Preglednica 2: Odstotek inhibicije rasti micelija glive $B$. bassiana pri različnih herbicidih in koncentracijah v primerjavi s kontrolnim obravnavanjem pri 15 in $25^{\circ} \mathrm{C}$ po 14 dneh ter razdelitev v posamezne razrede glede na obseg inhibicije.

\begin{tabular}{|c|c|c|c|c|c|c|c|c|c|c|c|}
\hline & & pyridate & $x$ & $\begin{array}{l}\text { fluazifop- } \\
\text { p-butyl }\end{array}$ & $x$ & foramsulfuron & $x$ & tembotrion & $X$ & $\begin{array}{l}\text { S- } \\
\text { metolachlor }\end{array}$ & $\mathrm{X}$ \\
\hline \multirow{2}{*}{$100 \%$} & $15^{\circ} \mathrm{C}$ & $59,17 d^{1}$ & 3 & $57,60 \mathrm{e}^{*}$ & 3 & 100 & 4 & $95,95 \mathrm{e}$ & 4 & $94,09 \mathrm{e}$ & 4 \\
\hline & $25^{\circ} \mathrm{C}$ & $64,65 d^{2}$ & 3 & $62,29 \mathrm{e}^{*}$ & 3 & $96,46 e^{*}$ & 4 & 90,77 de & 4 & $92,65 \mathrm{f}$ & 4 \\
\hline \multirow{2}{*}{$75 \%$} & $15^{\circ} \mathrm{C}$ & $54,34 d$ & 3 & $48,75 \mathrm{~d}$ & 2 & $96,38 e^{*}$ & 4 & $96,53 \mathrm{e}$ & 4 & $92,02 \mathrm{de}^{*}$ & 4 \\
\hline & $25^{\circ} \mathrm{C}$ & $47,97 \quad \mathrm{c}$ & 2 & $55,23 \mathrm{de}$ & 3 & $87,11 \mathrm{de}^{*}$ & 4 & 88,70 d & 4 & $88,82 e^{*}$ & 4 \\
\hline \multirow{2}{*}{$50 \%$} & $15^{\circ} \mathrm{C}$ & 50,44 & 3 & $46,06 \quad d$ & 2 & $93,76 \mathrm{e}$ & 4 & $91,44 \mathrm{e}^{*}$ & 4 & $90,78 d^{*}$ & 4 \\
\hline & $25^{\circ} \mathrm{C}$ & $40,36 \quad b$ & 2 & $49,43 \mathrm{~d}$ & 2 & $73,29 d$ & 3 & $94,98 \mathrm{e}^{\star}$ & 4 & $94,46 \mathrm{~g}^{*}$ & 4 \\
\hline \multirow{2}{*}{$25 \%$} & $15^{\circ} \mathrm{C}$ & $40,00 \quad \mathrm{c}$ & 2 & $18,89 \mathrm{c}$ & 1 & $82,58 \mathrm{~d}^{*}$ & 4 & $83,47 \quad d^{*}$ & 4 & $89,13 \mathrm{~d}^{*}$ & 4 \\
\hline & $25^{\circ} \mathrm{C}$ & $33,23 \quad b$ & 2 & $22,08 \quad \mathrm{c}$ & 1 & $48,52 \quad c^{*}$ & 2 & $62,68 \quad c^{*}$ & 3 & $76,64 d^{*}$ & 4 \\
\hline \multirow{2}{*}{$\begin{array}{l}12,5 \\
\% \\
\end{array}$} & $15^{\circ} \mathrm{C}$ & $24,72 \quad b$ & 1 & 5,66 & 1 & $69,07 \quad c^{*}$ & 3 & $51,06 \quad c^{*}$ & 3 & $74,25 \quad c^{*}$ & 3 \\
\hline & $25^{\circ} \mathrm{C}$ & $31,98 \quad b$ & 2 & 9,81 & 1 & $27,79 \quad b^{*}$ & 2 & $21,46 \quad b^{*}$ & 1 & $55,20 \quad c^{*}$ & 3 \\
\hline \multirow{2}{*}{$\begin{array}{l}6,25 \\
\% \\
\end{array}$} & $15^{\circ} \mathrm{C}$ & $28,26 b^{*}$ & 2 & $5,84 \quad b$ & 1 & $37,17 \quad b$ & 2 & $29,32 \quad b^{*}$ & 2 & $47,96 \quad b^{*}$ & 2 \\
\hline & $25^{\circ} \mathrm{C}$ & $34,03 \quad b^{*}$ & 2 & $11,57 \quad b$ & 1 & 12,55 ab & 1 & $0,00 \quad a^{*}$ & 1 & $18,66 b^{*}$ & 1 \\
\hline $0 \%$ & & $0,00 \quad a$ & & $0,00 \quad a$ & & $0,00 \quad a$ & & 0,00 & & $0,00 \quad a$ & \\
\hline
\end{tabular}

Legend: X - scoring categories of inhibition: 1 . class: harmless (<25\%), 2. class: slightly harmful (25-50\%), 3. class: moderately harmful (51-75\%), and 4. class: harmful (>75\%)

* significant difference of percent of mycelial growth inhibition between two temperatures $\left(15\right.$ and $\left.25^{\circ} \mathrm{C}\right)$

1,2 different lowercase letters show significant differences in mycelial growth inhibition among different concentrations within each herbicide at one temperature

Legenda: $\mathrm{X}$ - razred inhibicije: 1. razred: neškodljiv ( $<25 \%)$; 2. razred: malo škodljiv (25-50 \%); 3. razred: zmerno škodljiv (51$75 \%)$ in 4. razred: škodljiv (>75\%)

* statistično značilna razlika $\mathrm{v} \%$ inhibicije med temperaturama $\left(15\right.$ in $\left.25^{\circ} \mathrm{C}\right)$

${ }^{1,2}$ različne črke pomenijo statistično značilne razlike $\mathrm{v}$ inhibiciji med posameznimi koncentracijami pri enem herbicidu in eni temperaturi

Conditions established in soil after herbicide application (partial binding to clay and hummus particles, microbiological and chemical decomposition, rinsing, dissolving due to precipitation etc.) were simulated in this way. Beside all that, we were interested to see the effect of small amounts of herbicide residuals on entomopathogenic fungus $B$. bassiana. The later is very important to be able to evaluate the influence of residuals of herbicides used in previous crop on efficacy of mycoinsecticide based on B. bassiana used in current 
crop. Obtained results have confirmed that our decision was correct, since all of the studied herbicides had a significant fungistatic effect even at low concentrations.

If we take a look at the harmfulness classification (Table 2) of individual treatments we see that Smetolachlor, tembotrione and foramsulfuron are harmful for B. bassiana at $50 \%$ of field concentration (class 4), $\mathrm{S}$-metolachlor even at $25 \%$ concentration. Herbicides pyridate and fluazifop-P-butyl are moderately harmful (class 3) only at the highest tested concentrations. Laboratory experiments in vitro showed higher acceptability of pyridate and fluazifop-P-butyl usage together with the use of B. bassiana in integrated crop production in comparison to $\mathrm{S}$-metolachlor, tembotrione and foramsulfuron, that are inhibitory for mycelium growth even at low concentrations.

After collecting published results of many different experiments on B. bassiana and pesticides Klingen and
Haukeland (2006) observed that fungicides have the highest mycelium growth inhibitory effect, while insecticides and herbicides have a fungistatic effect. Detrimental effects of herbicides (especially terrestrial ones) on growth and sporulation of fungus $B$. bassiana was confirmed by many different researchers (Ambethgar, 2009; Gardner and Storey, 1985; Harrison and Gardner, 1992; Mietkiewski et al., 1989; Poprawski in Majchrowicz, 1995; Todorova et al., 1998; Wardle and Parkinson, 1992). In our study, effects of herbicides not commonly tested by other researchers were evaluated. Only Poprawski and Majchrowicz (1995) also observed fungicidal effect of metolachlor on $B$. bassiana. Similar herbicide from our study, Smetolachlor, also inhibited mycelium growth (93\%). We have to stress, that it is a similar kind of herbicide, not exactly the same one and that concentrations used in our study were lower compared to those by Poprawski and Majchrowicz (1995).

\section{CONCLUSIONS}

Based on the results of this essay, conclusions that entomopathogenic fungus $B$. bassiana is very sensitive to the herbicides tested can be made. Particularly at recommended, but as well as at lower field dosage, herbicides have strong fungistatic or even fungicidal effect. Preliminary tests on agar plates (in vitro) in laboratory conditions have limited application value and therefore can not be directly transformed in field practice. These results must be examined also in field trials (in situ). Besides of active ingredients the formulation of herbicide can also have fungistatic or fungicidal effect (Morjan et al., 2002) meaning that results can not be generalized for all the products containing the same active ingredient.

\section{ACKNOWLEDGEMENT}

This work was founded by Phytosanitary Administration of the Republic of Slovenia, Ministry of Agriculture, Forestry and Food of R Slovenia. We would like to thank also to manufacturers Karsia d.o.o.,
Bayer CropScience Slovenija and Syngenta Agro Slovenia for free samples of herbicides used in our essay.

\section{REFERENCES}

Ambethgar, V., Swamiappan, M., Rabindra, R. J., Rabindran, R. 2009. Influence of some herbicides on in vitro vegetative growth of Beauveria bassiana (Balsamo) Vuillemin. Resistant Pest Management Newsletter 19: 13-16.

Benz, G. 1987. Environment. V: Epizootiology of Insect Diseases (ur. Fuxa, R. in Tanada, J.). Willey, New York: 177-214.

Celar, F. A., Sekne, Š., Mesec, D., Kos, K. 2011. Učinek herbicidov in fungicidov na rast micelija entomopatogene glive Beauveria bassiana (Bals.) Vuill. = Effect of selected herbicides and fungicides on mycelial growth of entomopathogenic fungus Beauveria bassiana (Bals.) Vuill. V: Maček, J., Trdan, S. (ur.). Zbornik predavanj in referatov 10. slovenskega posvetovanja o varstvu rastlin,
Podčetrtek, 1.-2. marec 2011. Ljubljana: Društvo za varstvo rastlin Slovenije $=$ Plant Protection Society of Slovenia: 171-175.

Coremans-Pelseneer, J., 1994. Laboratory tests on the entomopathogenic fungus Beauveria. IOBC/WPRS Bull. 17,10: 147-154.

Gardner, W. A., Storey, G. K. 1985. Sensitivity of Beauveria bassiana to selected herbicides. J. Econ. Entomol. 78: 1275-1279.

Harrison, R.D., Gardner, W.A. 1992. Fungistasis of Beauveria bassiana by selected herbicides in soil. J. Entomol. 27: 233-238.

Hokkanen, H.M.T and R. Kotiluoto. 1992. Bioassay of the side effects of pesticides on Beauveria bassiana and 
Metarhizium anisopliae: standardized sequential testing procedure. World Pesticides Research Science Bulletin,11: 148-151.

Hummel, R.L., Walgenbach, J.F., Barbercheck, M.E., Kennedy, G.G., Hoyt, G.D., Arellano, C. 2002. Effects of production practices on soil-borne entomopathogens in western North Carolina vegetable systems. Environmental Entomology 31: 84-91.

Inglis, G.D., Goettel, M.S., Butt, T.M., Strasser, H. 2001. Use of Hyphomycetous Fungi for Managing Insect Pests. V: Fungi as Biocontrol Agents - Progress, Problems and Potential (ur. Butt, T.M., Jackson, C.W., Magan, N.). CABI Publishing, Walingford: 23-69.

Keller, S. 1986. Investigations on the effect of herbicides on aphid pathogenic Entomophthoraceae. V: Ecology of Aphidophaga (ur. Hodek, I.). Academia, Prague and Dordrecht: 493-497.

Keller, S. 1991. Les maladies fongiques des ravageur et leur importance pratique. Revue Suisse de viticulture, arboriculture, horticulture 23: 299-310.

Klingen, I., Haukeland, S. 2006. The soil as a reservoir for natural enemies of pest insects and mites with emphasis on fungi and nematodes. V: An Ecological and Societal Approach to Biological Control (ur. Eilenberg, J., Hokkanen, H.M.T.). Springer, Netherlands: 145-211.

Luz, C., Bastos, N., Nunes, R. 2007. In vitro susceptibility to fungicides by invertebrate-pathogenic and saprobic fungi. Mycopathologia 164: 39-47.

Mietkiewski, R.T, Pell, J.K, Clark, S.J. 1997. Influence of pesticide use on the natural occurrence of entomopathogenic fungi in arable soils in the UK: field and laboratory comparisons. Biocontr. Sci. Technol. 7: $565-575$.

Mietkiewski, R., Sapiecha, A., Mietkiewska, Z. 1989. Growth of entomopathogenic fungi on a medium containing herbicides used in orcharding. Acta Mycology 25: 35-50.

Moorhouse, E.R., Gillespie, A.T., Sellers, E.K., Charnley, A.K. 1992. Influence of fungicides and insecticides on the entomogenous fungus Metarhizium anisopliae, a pathogen of the vine weevil, Othiorhynchus sulcatus. Biocontrol Science and Technology 2: 49-58.

Morjan, W.E., Pedigo, L.P., Levis, L.C. 2002. Fungicidal effects glyphosate and glyphosate formulations on four species of entomological fungi. Envirommental Entomology 31: 1206-1212.

Poprawski, T.J., Majchrowicz, I. 1995. Effects of herbicides on in vitro vegetative growth and sporulation of entomopathogenic fungi. Crop Protection 14: 81-87.

Sterk, G., Hassan, S.A., Baillod, M., Bakker, F., Bigler, F., Blumel, S., Bogenschutz, H., Boller, E., Bromand, B., Brun, J., Calis, J.N.M., Coremans-Pelseneer, J., Duso, C., Garrido, A., Grove, A., Heimbach, U., Hokkanen, H., Jacas, J., Lewis, G., Moreth, L., Polgar, L., Roversti, L., Samsoe-Peterson, L., Sauphanor, B., Schaub, L., Staubli, A., Tuset, J.J., Vainio, A., Van de Veire, M., Viggiani, G., Vinuela, E., Vogt, H. 1999. Results of the seventh joint pesticide testing programme carried out by the IOBC/WPRS-Working Group 'Pesticides and Beneficial Organisms'. BioControl 44: 99-117.

Sterk, G., Heuts, F., Merck, N., Bock, J. 2003. Sensitivity of non-target arthropods and beneficial fungal species to chemical and biological plant protection products: Results of laboratory and semi-field trials. V: 1st International Symposium on Biological Control of Arthropods, Honolulu, 14-18 januar 2002, USDA Forest Service, Forest Health Technology Enterprise Team: 306313.

Todorova, S.I., Coderre, D., Duchesne, R.M. and Côté, J.C. 1998. Compatibility of Beauveria bassiana with selected fungicides and herbicides. Biological Control 27: 427433.

Wardle, D.A., Parkinson, D. 1992. The influence of the herbicide glyphosate on interspecific interactions between four soil fungal species. Mycol. Res. 96: 180186. 